prevalence of respiratory problems. However, little is known about the respiratory health of coffee plantation workers.

Methods A case-control study was carried out, whose sample was obtained by convenience sampling in four coffee farms in the region of Lavras/MG. The data were obtained by means of a questionnaire, occupational history collection, qualitative evaluation of work environments, spirometry and measurement of exhaled nitric oxide (FeNO).

Results 63 workers were evaluated (median age 43 years/tillage time 11 years). The general population has a chronic cough rate of $3.1 \%$, wheezing of $23.5 \%$ and dyspnea (MRC1) of $36.9 \%$ (PLATINO, 2006). In this study, coffee farmers had a higher prevalence only in the cough, rate of $6.6 \%$. This symptom was also found among coffee plantation workers in Tanzania $(23 \%)$ and also in Uganda in the Arabica and Robusta coffee factories. The group of workers also presented a tendency to lower values of FEV1 and still higher values of FeNO, but without reaching statistical significance. This finding was also found in another study in coffee plantations in Tanzania in which a rate of $13 \%$ FeNO above 25 ppb was observed among workers.

Conclusion Due to the importance of coffee for the Brazilian economy and the significant number of coffee workers, new studies with larger samples are necessary to verify the hypothesis and to guide health and preventive actions regarding respiratory problems in these workers

\section{SARCOIDOSIS IN TWO WORKERS MAKING LIGHT BULBS}

${ }^{1} S$ Ronsmans*, ${ }^{2} E$ Verbeken, ${ }^{1} S$ Keirsbilck, ${ }^{1} E$ Adams, ${ }^{3} R$ Swennen, ${ }^{1,4} B$ Nemery. ${ }^{1} U Z$ Leuven, Clinic of Occupational and Environmental Health, Leuven, Belgium; ${ }^{2} \mathrm{KU}$ Leuven, Department of Imaging and Pathology, Translational Cell and Tissue Research, Leuven, Belgium; ${ }^{3} \mathrm{KU}$ Leuven, Department of Earth and Environmental Science, Geology, Leuven, Belgium; ${ }^{4} \mathrm{KU}$ Leuven, Department of Public Health and Primary Care, Centre for Environment and Health, Leuven, Belgium

\subsection{6/oemed-2018-ICOHabstracts.1278}

Introduction Two out of about 30 workers in a light bulb production unit were diagnosed with 'sarcoidosis' and referred to our occupational health clinic in 2014.

Case reports A 27-year-old male (case A) was diagnosed with sarcoidosis in January 2013. He presented with fatigue, exertional dyspnea, mildly restricted pulmonary function (TLC $81 \%$ ) and mildly reduced diffusion capacity (DLCO 71\%). Chest imaging by computerised tomography showed a nodular pattern with lymphatic distribution and enlarged mediastinal lymph nodes. Histology of lymph node tissue (obtained by mediastinoscopy) revealed granulomas compatible with sarcoidosis. It came to light that one of his work colleagues also had sarcoidosis. This 33-year-old male (case B) had been diagnosed with sarcoidosis in 2008, based on a history of exertional dyspnea, abnormal chest radiography and an open lung biopsy showing granulomas.

Both men had worked, since 2005, as technical operators in a factory producing light bulbs. There was potential exposure to zirconium, mercury, thallium and thorium, but considerable exposure was mentioned to dust originating from the clipping of tubes made of 'fused quartz glass'. X-ray diffraction of settled dust samples demonstrated mainly amorphous silica, possibly with some cristobalite.
Subsequent microscopic examination of the mediastinal lymph node tissue (case A) and lung tissue (case B) under polarised light revealed multiple small birefringent crystals in relevant areas. Blood Lymphocyte Proliferation Test (LPT) was negative for beryllium and zirconium, but convincingly positive for nano-silica in case A. LPTs were negative for beryllium and nano-silica in case B (who was under corticosteroid therapy). Both patients improved clinically, radiologically and functionally after removal from exposure.

Discussion Several elements suggest that these two cases of 'pseudo-sarcoidosis' were caused by occupational exposure to silica.

\section{INFLAMMATORY PROFILE IN OCCUPATIONAL CHRONIC OBSTRUCTIVE PULMONARY DISEASE ATTRIBUTED TO DIFFERENT ENVIRONMENTAL FACTORS}

${ }^{1}$ LA Shpagina, ${ }^{1}$ OS Kotova, ${ }^{2} \mathrm{NI}$ Izmerova, ${ }^{1}$ IS Shpagin, ${ }^{1}$ ON Gerasimenko, ${ }^{1} \mathrm{GV}$ Kuznetsova, 'SA Karmanovskaya, 'LA Panacheva, 'L Yu Zyubina, 'SV Tretyakov. 'Novosibirsk State Medical University, Novosibirsk, Russian Federation; ${ }^{2}$ FSBSI 'Izmerov Research Institute of Occupational Health', Moscow, Russian Federation

\subsection{6/oemed-2018-ICOHabstracts. 1279}

Introduction Occupational exposures are of the major risk factors of chronic obstructive pulmonary disease (COPD). As these factors are different entities, there is a probability of numerous unique disease endotypes caused by certain industrial pollutants.

Methods The objective of the study was to evaluate inflammatory serum profiles and to discover potential biomarkers of COPD attributed to different environmental factors. It was an observational prospective study recruited 167 COPD subjects, 42 exposed to aromatic hydrocarbons 55 to inorganic dust and 70 tobacco smokers. Control group - 62 healthy workers. Groups were matched by demographics and smoking status. Serum pulmonary inflammation markers matrix metalloproteinase 7 (MMP7), monocyte chemotactic protein-1 (MCP1), interleukin $1 \beta$ (IL1 $\beta)$, interleukin $1 \beta$ receptor antagonist protein (IL1RA), transforming growth factor $\beta$ (TGF $\beta$ ), basic fibroblast growth factor (FGF2), vascular endothelial growth factor (VEGFA), superoxide dismutase 3 (SOD3), interleukin 12 (IL12), interleukin 17 (IL17) and activation-regulated chemokine (PARC/CCL18) level were assessed by ELISA. Multiple regression model was used to explore the relationships. ROC analysis and area under the curve (AUC) was used to evaluate diagnostic accuracy.

Result Significant differences between groups were found in IL1 $\beta(12,1 \pm 1,45 \mathrm{pg} / \mathrm{ml}$ in COPD due to chemicals, 12,1 $\pm 1,45 \mathrm{pg} / \mathrm{ml}$ in COPD due to dust and $0,2 \pm 0,10 \mathrm{pg} / \mathrm{ml}$ in COPD due to tobacco smoke), TGF $\beta(1228,9 \pm 130,30 \mathrm{pg} / \mathrm{ml}$, $421,2 \pm 29,02 \mathrm{pg} / \mathrm{ml}$ and $263,7 \pm 111,43 \mathrm{pg} / \mathrm{ml}$ respectively), FGF $2(0,1 \pm 0,07 \mathrm{pg} / \mathrm{ml}, 21,5 \pm 1,06 \mathrm{pg} / \mathrm{ml}$ and $9,3 \pm 0,77 \mathrm{pg} /$ $\mathrm{ml})$, VEGF A $(129,9 \pm 24,79 \mathrm{pg} / \mathrm{ml}, 489,2 \pm 73,93 \mathrm{pg} / \mathrm{ml}$ and $852,7 \pm 73,81 \mathrm{pg} / \mathrm{ml})$ and SOD3 $(1,4 \pm 0,08 \mathrm{ng} / \mathrm{ml}, \quad 11,3$ $\pm 0.90 \mathrm{ng} / \mathrm{ml}$ and $15,7 \pm 9,39 \mathrm{ng} / \mathrm{ml})$. In the multiple regression model, significant predictors were IL1 $\beta$, TGF $\beta$, VEGFA levels for chemical risk factor $(\mathrm{AUC}=0.9)$ and IL1 $\beta$, FGF2 for dust rick factor (AUC=0.8).

Conclusion Serum interleukin $1 \beta$, TGF $\beta$, FGF2 and VEGF A levels have the potential of being markers of COPD due to different environmental factors. 